\title{
SEDIMENTASI MUARA SUNGAI DI KOTA SORONG
}

\author{
Serly Marlina ${ }^{1)}$ \\ ${ }^{1), 2)}$ Program Studi Teknik Sipil Universitas Muhammadiyah Sorong \\ Jalan Pendidikan No 27 Kota Sorong, Propinsi Papua Barat \\ Email : serlymarlina723@gmail.com
}

\begin{abstract}
ABSTRAK
Kota Sorong merupakan wilayah yang membentang sepanjang pesisir bagian barat Propinsi Papua Barat. Salah satunya adalah muara Sungai Remu, yang mana sampai saat ini merupakan salah satu media transportasi laut dimana kapal-kapal masyarakat maupun nelayan keluar masuk. Tujuan penelitian ini yaitu untuk menganalisa sedimentasi muara sungai yang terjadi di wilayah Kota Sorong.Metode penelitian yang digunakan adalah dengan melakukan pengamatan secara langsung terhadap muara sungai yang ada di Kota Sorong.Kesimpulan yang dihasilkan adalah : 1) Permasalahan Penutupan Muara oleh sedimentasi baik dari porses transport sedimen pantai maupun transport sedimen dari sungai, merupakan suatu permasalahan yang klasik dalam upaya-upaya pengelolaan wilayah sungai dan pantai, apalagi jika dikaitkan dengan kejadian perubahan iklim .2) Perubahan iklim menyebabkan kenaikan muka air laut dan perubahan pola hujan di suatu wilayah pantai dan sungai.3) Kenaikan muka air laut berpengaruh terhadap pergerakan sedimen di pantai dan perubahan pola hujan berpengaruh terhadap pergerakan sedimen di wilayah sungai, yang kedua permasalahan tersebut akan bertemu di wilayah muara yang merupakan titik pertemuan antara suatu sungai dan wilayah pantai.4) Permasalahan penutupan muara tergantung pada kekuatan mana yang lebih dominan antara kekuatan penutup muara atau kekuatan pembuka muara. Kekuatan penutup muara terdiri dari faktor pergerakan sedimen pantai dan sungai, sedangkan kekuatan pembuka muara terdari seberapa besar debit dan kecepatan aliran sungai, serta seberapa besar fluktuasi air pasang surut di wilayah muara.5) Lebar muara sungai remu sudah cukup menunjang bagi kapal-kapal yang keluar dan masuk, akan tetapi masyarakat sangat terganggu karena masih banyak kapal-kapal yang parkir pada sepanjang aliran sungai menuju hulu (dermaga) dan masih banyaknya sampah disepanjang aliran Sungai Remu.
\end{abstract}

Kata Kunci : muara sungai remu, sedimentasi muara sungai, permasalahan penutupan muara 


\section{PENDAHULUAN}

Kota Sorong merupakan wilayah yang membentang sepanjang pesisir bagian barat Propinsi Papua Barat. Salah satunya adalah muara Sungai Remu, yang mana sampai saat ini merupakan salah satu media transportasi laut dimana kapal-kapal masyarakat maupun nelayan keluar masuk.Muara sangat terpengaruh oleh kondisi air daratan seperti aliran air tawar dan sedimen, serta air lauatan seperti pasang -surut , gelombang, dan masuknya air asin.Proses sedimen terjadi karena banyak penyebabnya saat musim hujan dan debit air megalami kenaikan dan akan terjadi luapan air sungai ( banjir ).Dalam situasi tersebut kecepatan aliran air luapan ( banjir ) sungai akan mengalami penurunan karena terambat oleh berbagai pematang - pematang, arus dan gelombang laut. Maka akan terjadi proses pelumpuran atau pegendapan material sedimen di kawasan muara sungai tersebut . Penelitian ini bertujuan untuk menganalisa sedimentasi muara sungai yang terjadi di wilayah Kota Sorong.

\section{METODOLOGI}

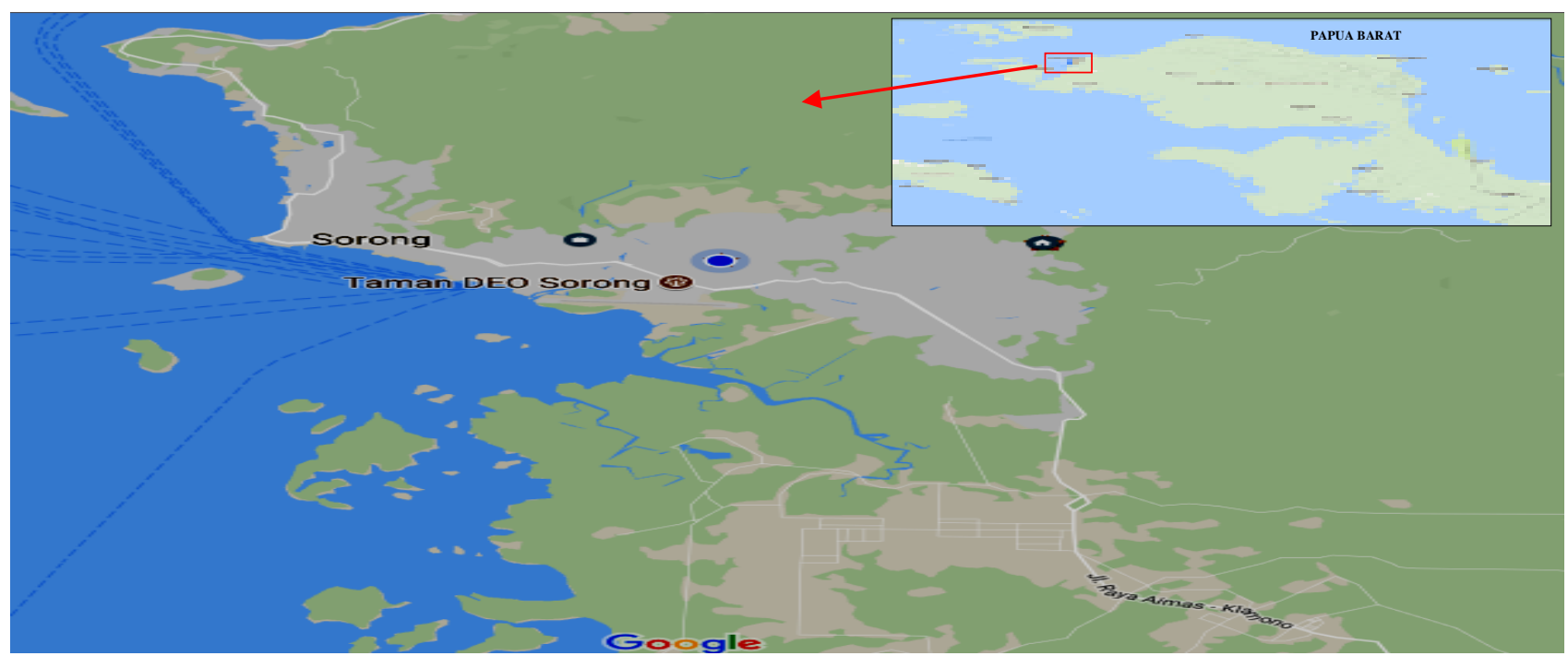

Gambar Lokasi

Tahapan penelitian yang digunakan adalah sebagai berikut :

1. Melakukan pengamatan langsung terhadap muara sungai di wilayah Kota Sorong

2. Mengolah data dari hasil yang telah di dapatkan pada saat melakukan pengamatan langsung .

3. Mengidentifikasi dan menganalisa permasalahan sedimentasi yang terjadi di muara sungai Kota Sorong.

Semua metode penulisan dan analisa dalam artikel ilmiah ini merujuk pada panduan penulisan tugas akhir Fakultas Teknik Universitas Muhammadiyah Sorong tahun 2014 (Pristianto , Amri \& Rusdi 2014 ). 


\section{HASIL DAN PEMBAHASAN}

Beberapa hasil penelitian terkait tema artikel ini adalah sebagai berikut :

1. Menurut Aris, Butudoka \& Pristianto , (2018) dalam artikelnya menyebutkan bahwa :

a. Permasalahan Penutupan Muara oleh sedimentasi baik dari porses transport sedimen pantai maupun transport sedimen dari sungai, merupakan suatu permasalahan yang klasik dalam upaya-upaya pengelolaan wilayah sungai dan pantai, apalagi jika dikaitkan dengan kejadian perubahan iklim (climate change).

b. Perubahan iklim menyebabkan kenaikan muka air laut dan perubahan pola hujan di suatu wilayah pantai dan sungai.

c. Kenaikan muka air laut berpengaruh terhadap pergerakan sedimen di pantai dan perubahan pola hujan berpengaruh terhadap pergerakan sedimen di wilayah sungai, yang kedua permasalahan tersebut akan bertemu di wilayah muara yang merupakan titik pertemuan antara suatu sungai dan wilayah pantai.

d. Permasalahan penutupan muara tergantung pada kekuatan mana yang lebih dominan antara kekuatan penutup muara atau kekuatan pembuka muara. Kekuatan penutup muara terdiri dari faktor pergerakan sedimen pantai dan sungai, sedangkan kekuatan pembuka muara terdari seberapa besar debit dan kecepatan aliran sungai, serta seberapa besar fluktuasi air pasang surut di wilayah muara

e. Jadi apabila untuk suatu keperluan sehingga muara sungai tersebut perlu dijaga supaya tetap mampu terbuka dan mengalahkan dominasi transport sedimen dari arah pantai dan sungai, maka harus kita perhatikan :

1) Bagaimana supaya bisa mendapatkan debit dan kecepatan aliran yang secara hidrolik mampu mendorong sedimen di muara

2) Bagaimana mengkondisikan fluktuasi pasang surut air laut sehingga juga dapat membantu membuka sedimentasi di muara.

3) Apabila kedua kekuatan pembuka itu sudah dioptimalkan dan belum mampu mengatasi permasalahan sedimentasi di muara secara alamiah, maka perlu pendekatan teknologi secara fisik dengan membangun bangunan pengatur sedimen di muara atau menerapkan teknologi seperti penerapan teknik fluidisasi pada muara sungai.

2. Menurut Pristianto, (2018) dalam artikelnya menyebutkan bahwa :

a. Transport sedimen adalah perpindahan tempat bahan sedimen granuler (non kohesif) oleh air yang sedang mengalir, dan gerak umum sedimen adalah searah aliran air.

b. Faktor- faktor yang menentukan transpor sedimen adalah sebagai berikut

1) Sifat-sifat aliran air (flow characteristics)

2) Sifat-sifat sedimen (sediment characteristics)

3) Pengaruh timbal balik antara sifat aliran air dan sedimen (interaction) 
c. Masalah-masalah yang berkaitan dengan transpor sedimen adalah sebagai berikut :

1) Kondisi alamiah, seperti erosi, perkiraan transpor sedimen di sungai, gerak sedimen di estuari, dan transpor sedimen sepanjang pantai.

2) Gangguan alam oleh bangunan artifisial, seperti agradasidegradasi pada bangunan air, pengendapan sedimen dalam waduk, dan lain-lain.

3) Transpor air, hal ini kaitannya dengan perencanaan saluran stabil terhadap proses erosi dan sedimentasi.

4) Transpor benda padat dalam pipa

d. Sedimen dapat diangkut dengan tiga cara, yaitu :

1) Suspended Load : butir bergerak di atas dasar secara melayang. Berat butir terus menerus dikompensasi oleh gerak turbulensi air.

2) Bed load: butir bergerak di dasar secara menggelinding (rolling), menggeser (sliding) atau meloncat (jumping).

3) Wash Load butir yang sangat halus dan berlindung di antara butir dasar (bed particles). Partikel tersebut bergerak melayang dibagian atas aliran dan tidak mengendap di dasar sungai.

e. Transpor sedimen dalam pipa penting dan diperlukan dalam bidang pemidahan endapan lumpur dan pengerukan (dredging). Manfaat system ini dalam kedua bidang tersebut adalah untuk memindahkan 3 sedimen/endapan pada minimum head loss tanpa pengendapan.

f. Aliran Slurry adalah suatu campuran dari zat padat dan zat cair. Contoh khas dari slurry adalah campuran zat padat - cair yang ditemukan dalam proses mineral tanaman dan dikeruknya material dari sungai dan bendung (Nayyar, 2000).

3. Menurut Pristianto \& Rusdi , ( 2015 ) yang meneliti tentang "Tinjauan Kondisi Fisik Perairan Teluk Bandara DEO Kota Sorong “, didapat kesimpulan antara lain :

a. Berdasarkan hasil ketentuan sesuai dengan baku mutu tingkat kebisingan ketentuan Menteri Negara Lingkungan Hidup Nomor KEP.48/MENLH/11/1996, tanggal 25 Nopember 1996 maka untuk daerah-daerah pemukiman seperti di Titik (A1) Ujung Landas Pacu Bagian Barat (75,8 dBA),dan A3 Ujung Landas Pacu Bagian Timur (84.7 dBA) di atas ambang baku mutu (55 dBA); sedangkan lokasi Fasilitas Umum seperti Lokasi Terminal Bandara atau titik A2 (75,9 dBA) dinyatakan di atas ambang baku mutu (60 dBA).

b. Hasil laboratorium terhadap sampel air dari muara Sungai Remu yang bermuara di perairan Teluk Bandara DEO Kota Sorong tersebut cukup besar bila dibandingkan dengan mutu baku yang di tetapkan dalam peraturan pemerintah No. 82 Tahun 2001, sehingga dari kualitas air Sungai Remu masuk dalam kualitas air kelas $\mathbf{4}$ (air untuk mengairi petanaman).

c. Lebar muara sungai remu sudah cukup menunjang bagi kapal-kapal yang keluar dan masuk, akan tetapi masyarakat sangat terganggu karena masih banyak kapal-kapal yang parkir pada sepanjang aliran sungai 
menuju hulu (dermaga) dan masih banyaknya sampah disepanjang aliran Sungai Remu.

d. Pendangkalan di wilayah muara terjadi tidak terlepas dari kontribusi erosi tanah yang berasal dari bagian kawasan hulu dari sungai yang lahannya sudah terbuka akibat kegiatan galian pasir tersebut. Kondisi semua itu ditambah dengan komulatif sampah yang tertumpuk di muara menyebabkan proses pendangkalan yang jika tidak segera diatasi akan menyebabkan masalah nantinya dibagian hulu. Muara yang dangkal akan menyebabkan terhambatnya kelancaran air dari sungai menuju laut, sehingga daerah pemukiman di sekitarnya akan rawan tergenang.

e. Pendangkalan yang terjadi di muara ke enam sungai di sekitar wilayah Teluk Bandara DEO menguatkan kekhawatiran akan proses lanjutannya dan pengaruhnya terhadap kondisi teluk itu sendiri

\section{KESIMPULAN}

Simpulan dari penelitian ini adalah :

1. Permasalahan Penutupan Muara oleh sedimentasi baik dari porses transport sedimen pantai maupun transport sedimen dari sungai, merupakan suatu permasalahan yang klasik dalam upaya-upaya pengelolaan wilayah sungai dan pantai, apalagi jika dikaitkan dengan kejadian perubahan iklim

2. Perubahan iklim menyebabkan kenaikan muka air laut dan perubahan pola hujan di suatu wilayah pantai dan sungai.

3. Kenaikan muka air laut berpengaruh terhadap pergerakan sedimen di pantai dan perubahan pola hujan berpengaruh terhadap pergerakan sedimen di wilayah sungai, yang kedua permasalahan tersebut akan bertemu di wilayah muara yang merupakan titik pertemuan antara suatu sungai dan wilayah pantai.

4. Permasalahan penutupan muara tergantung pada kekuatan mana yang lebih dominan antara kekuatan penutup muara atau kekuatan pembuka muara. Kekuatan penutup muara terdiri dari faktor pergerakan sedimen pantai dan sungai, sedangkan kekuatan pembuka muara terdari seberapa besar debit dan kecepatan aliran sungai, serta seberapa besar fluktuasi air pasang surut di wilayah muara.

5. Lebar muara sungai remu sudah cukup menunjang bagi kapal-kapal yang keluar dan masuk, akan tetapi masyarakat sangat terganggu karena masih banyak kapal-kapal yang parkir pada sepanjang aliran sungai menuju hulu (dermaga) dan masih banyaknya sampah disepanjang aliran Sungai Remu.

\section{DAFTAR PUSTAKA}

1. Aris, M., Butudoka, M. A., \& Pristianto, H. (2018). Pengaruh Perubahan Iklim Terhadap Potensi Penutupan Muara Oleh Sedimentasi.

2. Pristianto, H. (2018). Teori Aliran Sedimen Dalam Pipa.

3. Pristianto, H., \& Rusdi, A. (2015, March). Tinjauan Kondisi Fisik Perairan Teluk Bandara DEO Kota Sorong. In Prosiding Seminar Nasional Politeknik Kelautan dan Perikanan Sorong. ISBN (pp. 978-602).

4. Pristianto, H., Amri, I., \&Rusdi, A. (2014, May 9). Pedoman Penulisan Tugas Akhir Fakultas Teknik Universitas Muhammadiyah Sorong 2014. http://doi.org/10.17605/OSF.IO/4VTJM. 
